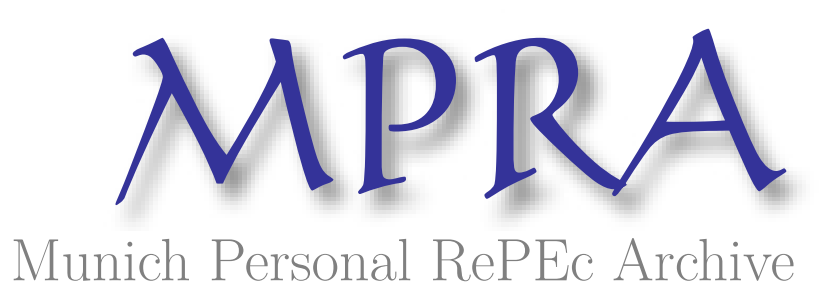

\title{
Holding Together or Falling Apart:Results of Gravity Equation of the CIS Trade
}

Kurmanalieva, Elvira and Vinokurov, Evgeny

Eurasian Development Bank

June 2011

Online at https://mpra.ub.uni-muenchen.de/32003/

MPRA Paper No. 32003, posted 04 Jul 2011 18:10 UTC 


\title{
Holding Together or Falling Apart:
}

\section{Results of Gravity Equation of the CIS Trade}

\author{
Elvira Kurmanalieva and Evgeny Vinokurov \\ Eurasian Development Bank ${ }^{1}$
}

June, 2011

\begin{abstract}
The main purpose of this paper is to assess intra-regional trade within the CIS by looking at the impact of numerous trade agreements in the region. Applying a gravity model on a set of 162 countries, we attempt to assess dynamics of intra-regional trade of various trade agreements between 1995 and 2008 in order to identify trade creation and trade diversion effects. We propose and empirically test three explanations of the CIS intra-regional trade: 1) home bias effect, 2) holding together effect and 3) holdup effect. Finally, we perform a simulation of potential trade and see to what extent twelve post-Soviet states and all their groupings would, ceteris paribus, have traded with each other.
\end{abstract}

Keywords: Soviet Union, CIS, EurAsEC, CES, Gravity equation, Trade potential, Panel data JEL Codes: C23, F13, F15, O52, O54

\footnotetext{
${ }^{1}$ Eurasian Development Bank, 220, Dostyk ave., 050051, Kazakhstan; phone $+7(727) 2444044$ Disclaimer: This article is the authors' personal opinion and is not necessarily the opinion or policy of the Eurasian Development Bank
} 


\section{Introduction}

The Soviet Union had been a highly integrated state of 15 republics with uniform infrastructure, technology and other determinants of trade. After the dissolution of the USSR, all countries went through severe structural shocks and deep economic crises. It took a decade for the former Soviet Union countries to become integrated into the world economy and trading system. While three of the former Soviet republics have now joined the European Union (EU), other twelve countries are still struggling on their own to adjust their economies to the changing economic conditions and terms of trade. A year after the break-up of the Soviet Union, Russia, Ukraine and Belarus initiated the first cooperation agreement that was later supported by the other nine countries. Since the creation of the Commonwealth of Independent States (CIS), numerous agreements have been signed concerning trade, investments and other tenets of economic cooperation. In 1996 Russia, Kazakhstan and Belarus signed a Customs Union agreement that became a core of the Eurasian Economic Community (EurAsEC-5), which was created in 2000 including Kyrgyzstan and Tajikistan. In 2003, an attempt to establish a four-country ${ }^{2}$ Common Economic Space (CES) has been launched, however, did not succeed.

Despite all these formal efforts, trade ties between the CIS countries have been rapidly digressing. From 1995 to 2009 the share of intra-regional trade as a percent of total trade of the CIS countries shrank from $30 \%$ to $16 \%$. The most dramatic decline of $58 \%$ occurred in intraregional trade among landlocked Central Asian countries ${ }^{3}$. At present, the $\mathrm{CIS}$ is a home for dozens of bilateral and multilateral trade agreements within and outside the region. In most cases they are not operational. The most recent integration attempt is a Russia-BelarusKazakhstan Customs Union (EurAsEC-3), launched in 2010, which has been followed by real policy changes, the adoption of unified tariff rate, and rapid progress toward deeper integration.

This paper makes an assessment of the relative impact of main multilateral trade agreements and groupings in the CIS. Applying a gravity model on a sample set of 162 countries covering the period between 1995 and 2008, we attempt to assess dynamics of intraregional trade in the region and explain it from the viewpoint of three main hypotheses: home bias effect, holding together regionalism and holdup effect. Finally, we perform a simulation of

\footnotetext{
${ }^{2}$ Russia, Ukraine, Belarus and Kazakhstan

${ }^{3}$ Kazakhstan, Kyrgyzstan, Tajikistan, Turkmenistan and Uzbekistan
} 
potential trade and evaluate to what extent the CIS and all its groupings overtrade or undertrade with each other and the world.

The paper proceeds as follows: Section II provides a brief literature survey, Section III discusses the comparative advantages of the regions and their changing trade patterns, Section IV applies a gravity model to quantify the effect of regional trade agreements, Section $\mathrm{V}$ estimates trade potentials and, finally, Section VI concludes the paper.

\section{Stylized Facts on Trade of the Former Soviet Union States}

A conventional method of empirical assessment of regional trade agreements uses a gravity modeling approach, which allows conducting econometric estimation of bilateral trade flows and assessing the impact of dummy variables. Since the dissolution of the Soviet Union there have been numerous studies discussing various aspects of disintegration and reintegration. Havrylyshyn and Al-Atrash (1998) documented the increase of trade openness at the initial stages of transition process in the former USSR countries, which indicated that the countries closer to the EU are more successful. However, Elborgh-Woytek (2003) found that openness has been falling since 1997 and will likely increase if market-oriented reforms were pursued more vigorously. Djankov and Freund (2000) explained home bias within Russia by imposition of high external tariffs and past linkages such as infrastructure, business networks and production chains. Freinkman et al (2004) concluded that the process of trade diversification away from the CIS remains incomplete in the CIS-7, and progress in the trade area was slower in the low-income CIS countries than in the high-income CIS members. De Sousa and Lamotte (2007) found a reduction of home bias within the former Soviet Union, former Yugoslavia and former Czechoslovakia from 1993 to 2001, which happened due to the transition process that had a different impact on the countries. By looking at disaggregated data, Shelburne and Pidufala (2006) concluded that over the past decade the CIS countries have significantly diversified their geographical destinations for exports of natural resources and raw materials but have been less successful in terms of promoting their manufactured goods. Most of the CIS countries under-rely on other CIS countries for their imports of manufactured goods but over-rely on them as a destination for their manufactured exports. Fidrmuc and Fidrmuc (2000) found that the former Soviet countries overtrade almost 43 times above the potential. Freinkman et al (2004) found that the five Central Asian countries and Moldova still overtrade with the CIS and undertrade with the rest of the world. Shepotylo (2009) estimated the 
potential trade using disaggregated trade data and found a disproportionally larger share of resource extraction oriented trade within the CIS countries.

Separate studies on Central Asia focus mostly on the landlocked nature of those countries. For instance, Raballand (2003) assessed a negative impact of the landlockedness and found that the number of border crossings along with long distance was crucial to explaining the level of trade flows. Grigorou (2007) and Carrere and Grigorou (2008) looked at the three factors that matter for the region: overland transportation costs, bargaining power with transit countries and the infrastructure of the latter. Moreover, of these three components, only the transit countries' infrastructure is specific to Central Asia: improvements in infrastructure of the transit-country raise trade three times more for Central Asian countries than for other landlocked countries. Grafe et al (2005) suggested that not only borders but also the trade barriers beyond the border are significant obstacles for market integration both within the countries and within Central Asia. ADB (2006) pointed to more significant trade barriers pertaining to trade policy in Central Asia: 1) relatively high tariffs with a complex tariff schedule; 2) frequent and unpredictable changes in the tariff schedule; 3) high implicit tariffs in the form of taxes that are levied on imported goods but not on domestically produced goods, or have higher rates for imported goods than for domestically produced goods; 4) explicit export taxes; and 5) prohibition and licensing of exports and imports of certain commodities, as well as large agricultural subsidies. According to the trade theory, a country's integration with a certain regional economic block can lead to an increasing convergence of trade structures and, thus, to the development of intra-industry trade. However, in regards to Central Asia, Kurmanalieva and Parpiev (2008) provided results of Helpman test and showed a disappointingly low degree of intra-industry and intra-regional trade for five landlocked countries in the CIS. Libman (2008) provides a firm-centered perspective on the regional integration and indentifies few important trends on regional integration. For instance, he suggested that recent economic success of Kazakhstan created all necessary conditions for the country to become an important center for development of regional multinationals and FDI, as well as act as a center of attraction for labor migration. Felipe and Kumar (2009) estimated the gains in trade derived from improvements in trade facilitation using the World Bank's Logistic Performance Index (LPI) and found significant gains that vary from $28 \%$ for Azerbaijan to $63 \%$ for Tajikistan.

Facilitating regional cooperation between landlocked and transit countries in order to upgrade the transit infrastructure should thus be a policy priority for governments and international institutions. Russia's position remains crucial for trade-related developments in 
the CIS region. However, the CIS countries are reluctant to commit themselves to 'hard' arrangements and remain wary of Russia's dominance, while Russia itself seems to dissociate itself from its partners (De Kort and Dragneva, 2006). However, the emergence of new initiatives for cooperation indicates that the CIS countries seem to realize existence of gains from regional cooperation.

There is a number of country studies that discuss pros and cons of the WTO accession. Lissovolik and Lissovolik (2006) assessed an 'outsider' status of Russia in the WTO, and suggest that the WTO membership would help the country to address an underlying bias in its trade, and would make the WTO nearly universal, thereby possibly giving a multilateral boost to global trade. In addition, Stern (2002) argued that the massiveness and diversity of Russia favor trade integration via the WTO membership rather than through regional arrangements. BabeckaKucharcukova and Maurel (2004) found potential for trade increases between transition countries and EU countries at the eve of Russia's accession to the WTO the through decline in the trade diversion effect, and institutional improvement. Khatibi (2008) also suggested institutional reforms along with the WTO accession as a long-term strategy Kazakhstan. Ukraine, which already joined the WTO in 2008 and opted for demand-based trade integration with the EU countries, would prefer to expand its integrated export potential with other CES countries in the mining, metallurgy, heavy engineering, aircraft and space industries (Konchyn, 2006). The analysis of trade of another WTO member, Kyrgyzstan, shows that the WTO membership and liberal trade policy made the country's bilateral trade grow and become more significant in the Central Asia (Kurmanalieva, 2008).

Summarizing the existing literature, we suggest three drivers of international trade dynamics of the post-Soviet countries. The first one, the home bias effect, is a widely-discussed problem in macroeconomics and international finance. It was first documented by McCallum (1995) where he showed that, for the United States and Canada, inter-province trade is twenty times larger than international trade, holding other determinants of trade constant. The home bias in trade was later documented among the OECD countries (Helliwell, 1997). According to this theory, given the fact that the post-Soviet countries all inherited similar economic structures and are located far from the rest of the world, they should have traded more with each other. Persistent, though declining, intra-regional trade can be explained by this effect. Another effect is a holding together regionalism - a view that is defined as regional integration projects emerging in a group of countries, which have recently belonged to a single political entity and have intensive infrastructural, economic and social ties between each other (Libman 
and Vinokurov, 2010). Djankov and Freund (2000) empirically underpinned this idea by showing that the past linkages limit the reorientation of trade in the former Soviet states. The final effect postulates that trade patterns of landlocked countries are determined to a greater degree by their relationships with transit coastal neighbors (highlighted by Gallup et al, 1999, Limao and Venables, 2001, and Faye et al, 2004). In most countries landlocked-transit countries' relations is a potential cause for holdup - opportunistic behavior by the transit country, which makes upstream countries poorer and less likely to invest in technology (Friberg and Tinn, 2009). From this point of view, analysis of trade relations between coastal Russia and landlocked Central Asian states seem to be very interesting. To our knowledge, there is still no study that looks at the intra-regional trade of the post-Soviet region from the view of three explanations. In this paper we try to fill in this gap.

\section{Trade Patterns and Structure}

After the dissolution of the Soviet Union, independent countries have concluded dozens of regional trade agreements with the world and among each other, creating a spaghetti bowl of trade agreements, including the CIS, EurAsEC, CES, ECO, the Customs Union and bilateral agreements with the EU and each other. Such activity allowed to keep high volumes of international trade, but did not give rise to openness. The figure 1 below shows that trade openness of the region is well above the world average and fluctuates slightly below full GDP coverage. This number is lower than the average of developed countries, but much higher than the average of least developed countries.

\section{Figure 1 about here}

Despite high growth in trade, the share of intra-regional trade in this region is low for all groupings (Figure 2). The main contributors to the regional trade are Russia, Ukraine, Belarus and Kazakhstan, which is indicated by a relatively high CES-4 intra-regional trade number (16\%). Landlocked Central Asian states exhibit the lowest intra-regional trade among all groupings. Trade with Europe and Asia comprises about 90\% of the post-Soviet countries' trade, while only about $10 \%$ of trade deals are done with other continents. This can be well explained by the natural resource bias of the CIS trade structure and geographical proximity to the fast growing emerging markets: the demand for natural resources of CIS countries comes mostly from China and the European Union. 
Figure $\mathbf{2}$ is about here

Let us now look closer at the product structure of trade in the CIS. The post-Soviet region trades about $10 \%$ with the rest of the world outside Eurasia. The structure is highly unbalanced with the highest share in mineral products (50\%) and metals (13\%). Machinery and transportation equipment constitute only about $6 \%$ and agriculture only $4 \%$ in total trade value. However, intra-regional trade in the region looks more balanced and diversified. Although it comprises only $15 \%$ in total trade, half of that value goes to mineral products and metals, and the rest is divided between agriculture, machinery, manufacturing and other non-specified items.

\section{Figure 3 is about here}

The graphs in the Appendix show trade structure for different groupings in the CIS. The CES, which consists of the biggest four countries in the region, has trade structure very similar to the one in the CIS . EurAsEC-5 and EurAsEC-3 only have 9\% of intra-regional trade and more concentration on natural resources outside the region, as well as within the region. With $82 \%$ in mineral products and metals, the Central Asian exports are concentrated in raw materials. However, among each other the countries in the region also trade agricultural goods.

\section{Home Bias, Holding Together, Holdup, and Regional Dummies}

Gravity model has roots in Newton's gravity law, which holds that gravitational force between two objects is positively related with their relative masses and negatively related with the distance between them. The estimated model contains data for 162 countries over the period 1995-2008. Trade data come from IMF DOT Statistics database. Zero-valued trade is omitted, since in this dataset missing trade means the absence of trade (Coe et al, 2002), and estimation is done on unbalanced panel dataset. All variables, excluding dummies, are in natural logarithms. Following Baldwin and Taglioni (2006), we allow for country and year heterogeneity, and use real values of variables (e.g. trade deflated by US CPI, real GDP). Following Carrere (2006), we chose Hausman-Taylor (1981) estimation technique, which allows fixing the omitted variables bias. As in Baldwin and Taglioni (2006), we allow for fixed time and 
each country's effect ${ }^{4}$. We add remoteness variable to control for the home bias effect, landlocked-transit dummy to control the holdup effect, and various interactions of infrastructure, cultural ties with regional dummies to control for the holding together effect.

First, we look at the interaction of RTA dummies and time dummies ${ }^{5}$ to see the evolution of integration processes for main trade groupings in the world and particularly within the post-Soviet states over the period of 1996-2008. Figure 4 demonstrates that Eurasia and its two main free trade frameworks, the EU and the ASEAN, demonstrate the increasing importance of intra-regional ties, while the importance of the CIS is declining and the WTO started growing at a slow pace since 2002. On the other hand, the regression results indicate that, unlike WTO members that trade $13 \%$ above the world average, the Eurasian countries trade $17 \%$ below the world average. Both coefficients present positive and statistically significant signs. Point estimate of -0.7 and -0.3 for the EU implies that when two countries of a pair belong to that grouping, they trade $50 \%[\exp (-0.7)-1=-0.5]$ below the level that would other similar countries trade. Similarly, ASEAN countries trade $18-30 \%$ below the sample average.

\section{Figure 4 is about here}

High positive coefficients in the regression results suggest that on average the CIS countries trade more than 4.5-10 times above the average in the sample. Other groupings that originated in the post-Soviet space follow a similar pattern, though mostly with statistically insignificant coefficients. The EurAsEC-3, a Customs Union of three countries, has larger but coefficient in regression but steeper decline over time than EurAsEC-5 and CES. EurAsEC-5 has a slower decline, which can be probably explained by a higher marginal effect of smaller countries in EurAsEC-5 $5^{6}$. CES dummy is somewhat close to EurAsEC-5. As to Central Asia, high and significant regression coefficients show that the region still trades almost 115 percent above the world average, but declining coefficients of interaction with time dummies suggest that the countries have been rapidly disintegrating over time. Landlocked nature and high dependence on natural resources of those countries suggest impossibility of increasing trade by creation of an agreement.

\footnotetext{
${ }^{4}$ Please refer to the Appendix for a short description of gravity model and data estimation techniques.

${ }^{5}$ We follow Brambor et al (2006) in interpreting interaction terms and thankful to Alexander Libman for this suggestion

${ }^{6}$ Large marginal effect of small countries has been documented by relatively large and increasing indices of integration in EDB (2009)
} 
Another variable that would show us the effect of home bias is relative remoteness. The first remoteness variable was proposed by Helliwell (1997) as separate variables for reporting and partner countries, and later utilized by Carrere (2006). The variable mirrors the fact that bilateral trade between countries is more likely when the average distance to all other trading partners is relatively high comparing to the distance between them. Putting it in a different way, "trade will be higher between country pairs that are far from the rest of the world than between country pairs that are close to the rest of the world" (Harrigan, 2002). We use the definition of remoteness introduced by Helliwell (1997) and commonly used in the gravity literature. Since we use bilateral trade flows, we use simple average between the two variables and divide it by their bilateral distance:

$$
R_{i j t}=\left(\frac{R_{i t}+R_{j t}}{2}\right) / D_{i j t}, \text { where } \quad R_{i t}=\sum_{k} \frac{Y_{k t}}{\sum_{k} Y_{k t}} D_{i k t} \quad \text { and } \quad R_{j t}=\sum_{k} \frac{Y_{k t}}{\sum_{k} Y_{k t}} D_{j k t}
$$

The results of remoteness variables estimations are similar to other estimations and in general support our expectations. The variable has a positive sign, as expected, and suggests that $1 \%$ of increase in the countries' relative closeness results in $0.2-0.3 \%$ increase in trade. Almost similar results are derived for interaction of remoteness with the WTO member countries. However, interaction terms of remoteness with other Eurasian dummies, unfortunately, are in most cases not significant. This suggests that the geographical proximity make them already close enough to each other (high and significant RTA dummy effect).

The holding together variable is represented by interaction terms of infrastructure variable and RTA dummies. We use a standard specification of infrastructure by including index for the development of infrastructure, as was first suggested by Limao and Venables (2001). It is constructed as an average of the density of the road network, the paved road network, the rail network, and the number of main telephone lines per person. For the world trade infrastructure this variable has a positive and significant sign. However, the marginal effect is very small, bringing about $0.004 \%$ of improvement in trade. Perhaps our variable does not capture cross-country infrastructure that is more important for trade rather than countryspecific infrastructure. Infrastructure variable is not significant for the CIS region, even though the variable has the expected positive sign.

Another variable that would represent a factor that may hold countries together is a common language dummy. In regression results it has an expected positive sign and suggests 
that countries that speak same language tend to trade $50-60 \%$ above average. In the CIS it is EurAseEC-5 grouping that is still holding together in terms of speaking common language.

Finally, we test the holdup variable, which is taken from Friberg and Tinn (2009). It is defined as a dummy variable:

$$
H U_{i j}= \begin{cases}0 & \text { if no transit country needed for } \mathrm{i} \text { to trade with } \mathrm{j} \\ 1 & \text { if trade between } \mathrm{i} \text { and } \mathrm{j} \text { has to pass a transit country }\end{cases}
$$

This variable has the expected negative sign in almost all estimations. For the world trade it suggests that trade which has to pass through a transit country is usually $20 \%$ below the sample average, while for the WTO members this coefficient is slightly higher (25\%). We also use an interaction of holdup (HU) dummy with RTA dummies. Holdup dummy exhibits different signs for various regions. In the CIS trade between transit and landlocked countries and among landlocked countries is $12 \%$ below the world average though the coefficient is not statistically significant and in the ASEAN region this number is even larger, 55\%.

\section{Trade Potentials}

For estimation of potential trade we apply out-of-sample technique, when the gravity model is estimated on a sample that excludes the group of interest, and only the coefficients of estimated equations are applied for quantification of trade potential.

It seems that home bias effects still have strong impact on the development of postSoviet integration that is mostly driven by inter-governmental agreements. Fidrmuc and Fidrmuc (2003) predicted potential trade 43 times lower than the actual among the former Soviet countries. Broadman (2005) found significant variation of potential trade among the CIS countries, with some of them significantly overtrading, like Belarus and Kyrgyzstan, some significantly undertrading, like Armenia and Georgia, while the biggest economies -Russia, Ukraine and Kazakhstan - trading as predicted.

\section{Figure 5 is about here}

Figure 5 is an additional evidence of findings of previous studies and our observations of the dominating home bias effect and holding together regionalism. All regional grouping in the CIS overtrade with each other with the highest overtrading coefficient for the EurAsEC-5 and EurAsEC-3. Together the CIS countries traded four times of their potential levels in 1995 and 
now trade three times above the potential. Four CES countries that have the highest share of intra-regional trade in the CIS have flatter reduction of actual trade and gradual approache their potential level. The steepest decline of the coefficient is observed for the Central Asian countries that traded six times above potential in 1995, and only three times in 2008.

\section{Conclusion}

The results of our exercise demonstrate that the CIS countries still highly overtrade with each other, even though the significance of home bias is decreasing over time. The result of the significant coefficient of the holdup dummy provides additional evidence of the importance of cooperation between landlocked and transit countries in the region. We could not find any evidence of the significant effect of similarity in infrastructure, which points at a cross-border infrastructure as a better determinant of trade. However, we believe that cross-border infrastructure, cultural ties and economic interdependence do have a significant impact on the presence of home bias.

The findings point to the need for a comprehensive set of policies to enhance regional cooperation initiatives and mitigate the negative holdup effect in the post-Soviet space. Such a comprehensive response is particularly important in the view of current global imbalances and slowdown in global consensus. Increased resources and closer cooperation between government agencies and business associations are necessary features of policy implementations. This paper underlines the fact that gravity regression is an invaluable tool of empirical research to improve understanding of the effect of the RTAs. Widening the number of commodity groups and extending the scope of research would further deepen our insights.

What is the next step for further integration in the CIS region after the creation of the Customs Union between Russia, Kazakhstan and Belarus? It seems that the bigger countries represent better candidates for initial integration steps, which was supported by a high share of intra-regional trade and slower decline in overtrading effect of the CES. Inclusion of another big country - Ukraine - is possibly the best candidate to join EurAsEC-3 and create of the core of post-Soviet integration. This core can subsequently grow and attract smaller countries that will have a larger marginal effect of integration. 


\section{References}

Anderson, J. (1979) A Theoretical Foundation for the Gravity Equation, American Economic Review 69, 106-116.

Anderson, J.E. and E. Van Wincoop (2003) Gravity with Gravitas: A Solution to the Border Puzzle. American Economic Review 93(1), 170-192.

Asian Development Bank (2006) Central Asia: Increasing Gains from Trade Through Regional Cooperation in Trade Policy, Transport, and Customs Transit, ADB Report.

Babecka-Kucharcukova, O. and M. Maurel (2004) Russia's Accession to the WTO: the Potential for Trade Increase, Journal of Comparative Economics 32(4), 680-699.

Baldwin, R. and D. Taglioni (2006) Gravity for Dummies and Dummies for Gravity Equations, NBER Working Paper No. 12516, September 2006.

Bergstrand, J. H. (1985) The Gravity Equation in International Trade: Some Microeconomic Foundations and Empirical Evidence, The Review of Economics and Statistics 67, 474-481.

Brambor, T., and W.R. Clark, and M. Golder (2006) Understanding Interaction Models: Improving Empirical Analyses, Political Analysis 14, 63-82.

Carrere, C. (2006) Revisiting the Effects of Regional Trading Agreements on Trade Flows with Proper Specification of the Gravity Model, European Economic Review 50(2), 223-247.

Carrere, C. and C. Grigorou (2008) Landlockedness, Infrastructure and Trade: New Estimates for Central Asian Countries, CERDI Working Paper No. 2008.01, January 2008.

Coe, D.T., A. Subramanian, N. Tamirisa T. and R. Bhavnani (2002) The Missing Globalization Puzzle, IMF Working Paper WP/02/171.

De Kort, J. and R. Dragneva (2006) Russia's Role in Fostering the CIS Trade Regime, MPRA Paper No. 21291, March 2010.

De Sousa, J. and O. Lamotte (2007) Disintegration, Transition and Trade, Economics of Transition 15(4), 825-843.

Djankov, S. and C. Freund (2000) Disintegration and Trade Flows: Evidence from the Former Soviet Union, World Bank WPS No. 2378, June 2000.

Egger, P. (2002) An Econometric view on the Estimation of Gravity Models and the Calculation of Trade Potentials. The World Economy 25, 297-312.

Elborgh-Woytek, K (2003) Of Openness and Distance: Trade Developments in the Commonwealth of Independent States, 1993-2002, IMF Working Paper No. 03/207, October 2003.

Evenet, S.J. and W. Keller (2002) On Theories Explaining the Success of the Gravity Equation, Journal of Political Economy 110, 281-316.

Felipe, J. and U. Kumar (2009) The Role of Trade Facilitation in Central Asia: A Gravity Model, Asian Development Bank, November 2009. 
Fidrmuc, J. and J. Fidrmuc (2000) Disintegration and Trade, Review of International Economics 11(5), 811-829.

Frankel, J. A. (1997) Regional Trading Blocs in the World Economic System, Institute for Internal Economics, Washington, D.C.

Freinkman, L. M., Evgeny Polyakov, and Carolina Revenco (2004) Trade Performance and Regional Integration of the CIS Countries, World Bank Working Paper No. 38.

Friberg, R. and K. Tinn (2009) Landlocked Countries and Holdup, Stockhold School of Economics, mimeo.

Gallup, J.L., J.D. Sachs and A.D. Mellinger (1999) Geography and Economic Development, International Regional Science Review 22, 179-232.

Grafe, C. and M. Raiser and T. Sakatsume (2005) Beyond Borders: Reconsidering Regional Trade in Central Asia, EBRD Working paper No. 95, December 2005.

Grigorou, C. (2007) Landlockedness, Infrastructure and Trade: New Estimates for Central Asian Countries, World Bank WPS 4335, August 2007.

Hausman, A. and E. Taylor (1981) Panel Data and Unobserved Individual Effects, Econometrica 49, 13771398.

Havrylyshyn, O. and H. Al-Atrash (1998) Opening Up and Geographic Diversification of Trade in Transition Economies, IMF Working Paper No. 98/22, February 1998.

Helliwell, J.F. (1997) National Borders, Trade and Migration, Pacific Economic Review 2 (3), 165-185.

Khatibi, A (2008) Kazakhstan's Accession to the WTO: A Quantitive Assessment ECIPE Working Paper No. $02 / 2008$.

Konchyn, V (2006) The Evolution of Ukrainian Economy: New Trade Theory Evidence, MPRA Paper No. 588, November 2007.

Krueger, A. O (1999) Trade Creation and Trade Diversion under NAFTA, NBER Working Paper No. 7429.

Kurmanalieva, E. (2008) Empirical Analysis of Kyrgyz Trade Pattern, Eurasian Journal of Business and Economics 2008, 1 (1), 83-97.

Kurmanalieva, E. and Z. Parpiev (2008), Geography and Trade in Central Asia, EERC Research Grant Paper RO6-085.

Libman, A. (2008) Regional Integration in Central Asia: A Firm-Centered View, MPRA Paper No. 10939, October 2008 .

Libman, A. and E. Vinokurov (2010) Holding Together Regionalism and the Interaction of Functional Bureaucracies, MPRA Paper No. 23217, June 2010.

Limao, N. and A.J. Venables (2001) Infrastructure, Geographical Disadvantage and Transport Costs, World Bank Economic Review 15, 451-479.

Lissovolik, B. and Y. Lissovolik (2006) Russia and the WTO: The "Gravity" of Outsider Status, IMF Staff Paper 53(1). 
Poyhonen, P. (1963) A Tentative Model for the Volume of Trade Between Countries, Weltwirtschaftliches Archiv 90, 93-99.

Raballand, G. (2003) Determinants of the Negative Impact of Being Landlocked on Trade: an Empirical Investigation Through the Central Asian Case, Comparative Economic Studies 45, 520-536.

Raballand, G., A. Kunth and R. Auty (2005) Central Asia's Transport Cost Burden and its Impact on Trade, Economic Systems 29, 6-31

Rose, A. K. (2000) One Money, One Market: Estimating the Effect of Common Currencies on Trade, Economic Policy 30, 9-45.

Shelburne, R.C. and O. Pidufala (2006) Evolving Trade Patterns in the CIS: The Role of Manufacturing, UNECE Discussion Paper No. 2006.2, September 2006.

Shepotylo, O. (2009) Gravity with Zeros: Estimating Trade Potential of CIS Countries, Discussion Paper No. 16, Kyiv School of Economics, March 2009.

Stern, R.M. (2002) An Economic Perspective on Russia's Accession to the WTO, The University of Michigan Discussion Paper No. 480, June 2002.

Tinbergen, J. (1962) Shaping the World Economy: Suggestions for an International Economics Policy, The Twentieth Century Fund, New York.

Vinokurov E. et al. (2010) The System of Indicators of Eurasian Integration. Eurasian Development Bank, Almaty. 


\section{Appendix}

\section{Trading structure of regional groups in the CIS}

\section{EurAsEC-5}

Total exports

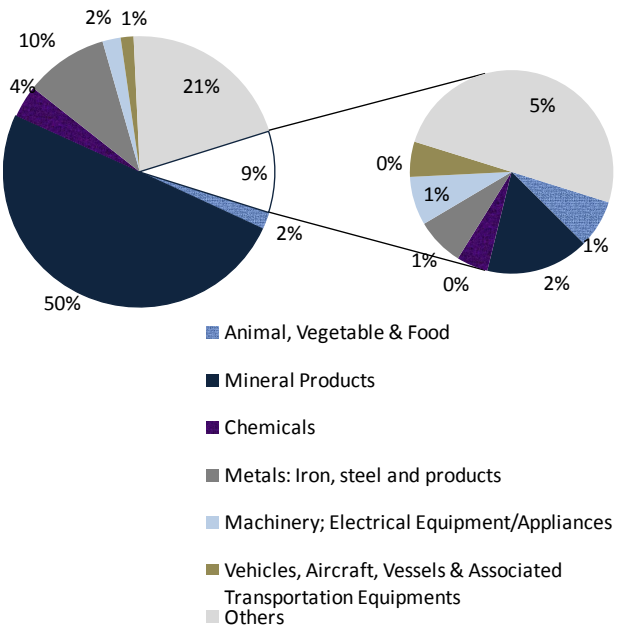

Single Economic Space

Total exports

Intra-regional trade

$3 \% 2 \%$

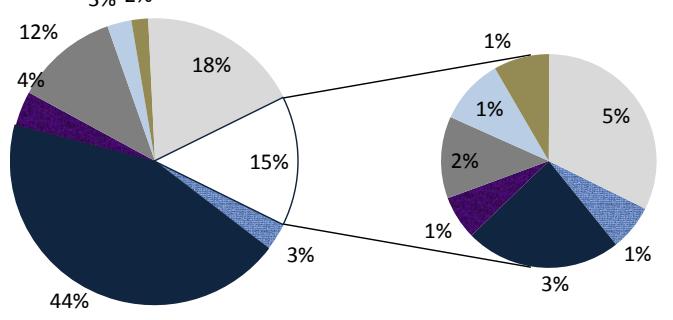

Animal, Vegetable \& Food

- Mineral Products

- Chemicals

Metals: Iron, steel and products

Machinery; Electrical Equipment/Appliances

- Textile \& Footwear

Others

\section{EurAsEC-3 Customs Union}

Total exports

Intra-regional trade

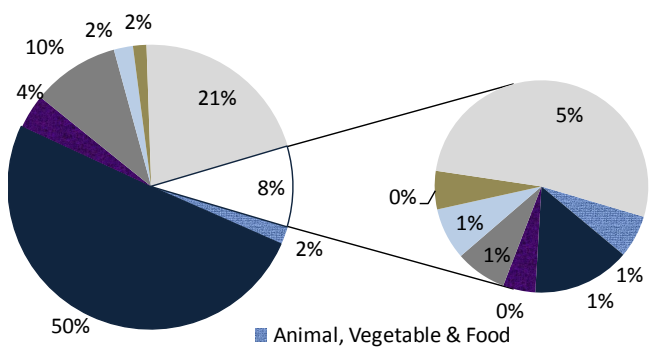

- Mineral Products

- Chemicals

Metals: Iron, steel and products

Machinery; Electrical

Equipment/Appliances

Vehicles, Aircraft, Vessels \& Associated

Transportation Equipments

\section{Central Asia}

Total exports

Intra-regional trade

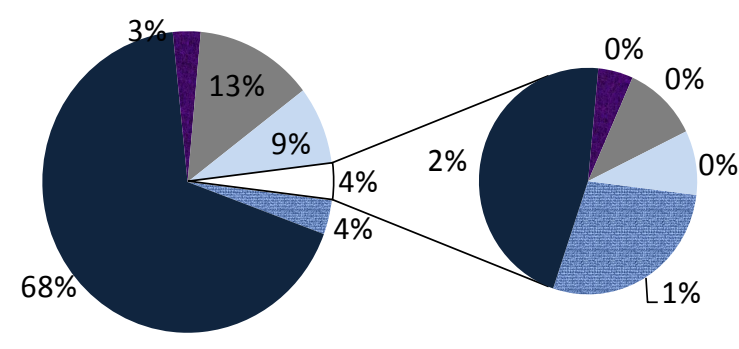

留 Animal, Vegetable \& Food

- Mineral Products

- Chemicals

Metals: Iron, steel and products

Others 


\section{Basics of Gravity Model}

Gravity model of international trade takes roots from Newton's gravity equation, and relates the trade between a pair of countries to their economic mass, often measured by their respective GDPs, and the distance between them. It was brought into estimation of international trade by Tinbergen (1962) and Poyhonen (1963). Anderson (1979) and Bergstrand (1985), Helpman and Krugman (1985) and Evenet and Keller (2002) developed theoretical justifications based on increasing returns to scale, imperfectly competitive markets and firmlevel product differentiation. Anderson and van Wincoop (2003) improved empirical microfoundation of the gravity equation by introducing theoretical and practical way of derivation of a "multilateral resistance" term.

A great volume of empirical literature use gravity equation for estimation of trade, investments and other bilateral transactions. The most notable estimations of bilateral trade flows are Frankel (1997) and Rose (2000). Egger (2002) suggested a correct way of controlling for heterogeneity in gravity equation on panel data and estimation of trade potentials. Finally, Baldwin and Taglioni (2006) sorted out the empirical specifications and use of dummy variables. We follow their specification as:

$$
\frac{V_{i j}}{P_{U S A}}=\tau_{i j}^{1-\sigma}\left(\frac{G D P_{i}}{P_{i}^{G D P}} \times \frac{G D P_{j}}{P_{j}^{G D P}}\right) \text {, where } \tau_{i j}=f \text { ist } t_{i j}, \text { otherstuff }
$$

Despite recent suggestions of two-stage non-linear estimations (Helpman et al, 2008) we favor the Hausman-Taylor (Hausman-Taylor, 1981) estimation that became a widely accepted and standard technique for estimation of gravity model (Egger, 2002 and Carrere, 2006) ${ }^{7}$. The Hausman-Taylor method allows for the inclusion of time-invariant variables in trade projections and circumvents the problem of an ad hoc estimation of the country pair-specific dummy variable needed for a projection based on the fixed-effects estimator. In addition, it removes the correlation between the error term and included variables which often plagues random-effects estimation

\footnotetext{
${ }^{7}$ Helpman et al (2008) proposes treatment of zero-trade and asymmetric trade flows. But we still think that low trade volumes (no matter if unidirectional or two-way low volumes) signify low development of trade relations. Thus, treatment of multilateral resistance and unobserved effect seem to us more important
} 
Data Definition and Sources

\begin{tabular}{|l|l|l|}
\hline Name & Description & Source \\
\hline Trade & $\begin{array}{l}\text { Log of bilateral trade (exports + imports) } \\
\text { deflated by US CPI }\end{array}$ & $\begin{array}{l}\text { DOT Statistics, IMF and IFS, } \\
\text { IMF }\end{array}$ \\
\hline Distance & $\begin{array}{l}\text { Log of great circle distance between capital } \\
\text { cities }\end{array}$ & \\
\hline Income & Log of Product of Real GDPs & WDI, World Bank \\
\hline Wage difference & Log of Product of GDPs per capita & WDI, World Bank \\
\hline Infrastructure & $\begin{array}{l}\text { Log of simple average of Limao-Venables } \\
\text { (2001) infrastructure variable }\end{array}$ & WDI, World Bank \\
\hline Remoteness & $\begin{array}{l}\text { Log of simple average of remoteness variable } \\
\text { Common border }\end{array}$ & $\begin{array}{l}\text { WDI, World Bank and } \\
\text { distance }\end{array}$ \\
\hline Common lanugage & 1 if share common, 0 otherwise & CIA Fact book \\
\hline HU dummy & $\begin{array}{l}1 \text { if there is potential to holdup, and 0 } \\
\text { otherwise }\end{array}$ & $\begin{array}{l}\text { Candlocked - Transit countries } \\
\text { from global map }\end{array}$ \\
\hline RTA dummy & 1 for country pairs that belong to RTA, and 0 \\
otherwise & Wikipedia \\
\hline Interaction variables & RTA dummy multiplied by variable & \\
\hline
\end{tabular}


Results of gravity equation

\begin{tabular}{|c|c|c|c|c|c|c|c|c|c|}
\hline VARIABLES & $\mathrm{FE}$ & $\mathrm{RE}$ & HT & HT & HT & HT & HT & HT & HT \\
\hline $\begin{array}{l}\text { Distance } \\
\end{array}$ & $0.634^{* * *}$ & -0.557**** & $-0.595^{* * * *}$ & $-0.638^{* * * *}$ & -0.616*** & $\begin{array}{l}-0.644^{* * * *} \\
\end{array}$ & -0.605*** & -0.612*** & $-0.604^{* * * *}$ \\
\hline GDP & $\begin{array}{l}10.154 * 4 \\
0.367^{* * * *}\end{array}$ & $\begin{array}{l}0.398^{* * * *} \\
0.104\end{array}$ & $\begin{array}{l}{[0.147]} \\
0.395 * * *\end{array}$ & $\begin{array}{l}{[0.147]} \\
0.383 * * *\end{array}$ & $\begin{array}{l}\text { [0.147] } \\
0.399 * * *\end{array}$ & $\begin{array}{l}{[0.147]} \\
0.383^{* * * *}\end{array}$ & $\begin{array}{l}{[0.147]} \\
0.398^{* * * *}\end{array}$ & $\begin{array}{l}{[0.147]} \\
0.384 * * *\end{array}$ & $\begin{array}{l}{[0.147]} \\
0.399 * * *\end{array}$ \\
\hline GDP percapita & [0.045] & {$\left[\begin{array}{l}{[0.031]} \\
-0.148 * * *\end{array}\right.$} & [0.031] & {$\left[\begin{array}{ll}{[0.030]} \\
-0.130 * * *\end{array}\right.$} & {$[0.031]$} & {$\left[\begin{array}{l}{[0.030]} \\
-0.130 * * *\end{array}\right.$} & {$\left[\begin{array}{l}{[0.031]} \\
-0.148 * * *\end{array}\right.$} & $-0.030]$ & {$[0.031]$} \\
\hline GDP per capita & $\begin{array}{l}-0.124 * * * \\
{[0.044]}\end{array}$ & $\begin{array}{l}-0.148^{* * * *} \\
{[0.030]}\end{array}$ & $\begin{array}{l}-0.144 * 6+* \\
{[0.030]}\end{array}$ & {$\left[\begin{array}{l}-130 \\
{[0.029]}\end{array}\right.$} & $\begin{array}{l}-0.149 * 4 * \\
{[0.030]}\end{array}$ & {$[0.029]$} & $\begin{array}{l}-0.148 * 0 ; \\
{[0.030]}\end{array}$ & $\begin{array}{l}-0.132^{* * * *} \\
{[0.029]}\end{array}$ & $\begin{array}{l}-0.149^{* * * 4} \\
{[0.030]}\end{array}$ \\
\hline Common border & $\begin{array}{c}\mathbf{0 . 3 1 0 ^ { * * * * }} \\
{[0.020]}\end{array}$ & $\begin{array}{c}\mathbf{0 . 4 0 2 * * *} \\
{[0.069]}\end{array}$ & $\begin{array}{c}0.356 * * * \\
{[0.070]}\end{array}$ & $\begin{array}{c}0.226 * * * \\
{[0.068]}\end{array}$ & $\begin{array}{c}\mathbf{0 . 3 9 3 * * *} \\
{[0.073]}\end{array}$ & 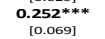 & $\begin{array}{c}\mathbf{0 . 4 0 0 * * *} \\
{[0.073]}\end{array}$ & $\begin{array}{c}\mathbf{0 . 2 7 1 * * *} \\
{[0.069]}\end{array}$ & $\begin{array}{c}0.396 * * * \\
{[0.073]}\end{array}$ \\
\hline Common language & $\begin{array}{l}0.530^{* * * *} \\
0.0211\end{array}$ & $\begin{array}{l}0.590^{\circ * * *} \\
{[0.043}\end{array}$ & $0.601 * * *$ & $\begin{array}{l}0.518^{* * *} \\
0.033\end{array}$ & $0.587^{7 * * *}$ & $0.533 * * *$ & $0.603^{* * * *}$ & $0.525 * * *$ & $0.602^{2 * * *}$ \\
\hline Remoteness & $1.663^{* * * *}$ & $0.378^{* * * *}$ & $0.372^{* * *}$ & $0.266^{*}$ & $0.326^{* *}$ & $0.267^{*}$ & $0.277^{*}$ & $0.267^{*}$ & $0.278^{*}$ \\
\hline Infrastructure & $0.006^{*}$ & $\begin{array}{l}{[0.144]} \\
0.001\end{array}$ & $\begin{array}{l}{[0.148]} \\
\mathbf{0 . 0 0 1}\end{array}$ & $\begin{array}{l}{[0.148]} \\
0.004^{* * *}\end{array}$ & $\begin{array}{l}{[0.148]} \\
0\end{array}$ & $\begin{array}{l}{[0.148]} \\
0.004 * * *\end{array}$ & $\begin{array}{l}{[0.148]} \\
0.001\end{array}$ & $\begin{array}{l}{[0.148]} \\
0.004^{* * * *}\end{array}$ & $\begin{array}{l}{[0.148]} \\
\text { 0.001 }\end{array}$ \\
\hline Holdup & $\begin{array}{l}{[0.003] *} \\
-\mathbf{0 . 4 2 7 * * *}\end{array}$ & $\begin{array}{l}{[0.002] *} \\
-0.253^{* * * *}\end{array}$ & $\begin{array}{l}{[0.002]} \\
-0.300^{* * * *}\end{array}$ & $\begin{array}{l}{[0.001]} \\
-\mathbf{0 . 1 8 0 * * *}\end{array}$ & $\begin{array}{l}{[0.002]} \\
-0.228 * * *\end{array}$ & $\begin{array}{l}{[0.001]} \\
-\mathbf{0 . 2 4 3 * * *}\end{array}$ & $\begin{array}{l}{[0.002]} \\
-0.217 * * *\end{array}$ & $\begin{array}{l}{[0.001]} \\
-0.243 * * *\end{array}$ & $\begin{array}{l}{[0.002]} \\
-0.217 * * *\end{array}$ \\
\hline & & {$[0.033]$} & {$[0.035]$} & & {$[0.035]$} & & [0.032] & {$[0.029]$} & [0.032] \\
\hline wTo & $0.200 * * * *$ & $0.128 * * * *$ & $0.128 * * *$ & $0.061 * * * *$ & $0.130 * * * *$ & $0.065 * * *$ & $0.129 * * * *$ & $0.065 * * *$ & $0.129 * * * *$ \\
\hline WTO-Remoteness $^{1}$ & $1.539 * * *$ & $0.367 * *$ & $0.358^{* * *}$ & & o. $330^{* * *}$ & & $0.277^{*}$ & & $0.273^{*}$ \\
\hline WTO-Infrastructure ${ }^{1}$ & $\begin{array}{l}\text { O.010**** } \\
\text { [0.003] }\end{array}$ & o.005*** & $\begin{array}{l}0.005 * * * \\
\text { [0.002] }\end{array}$ & & o.005*** & & o.005*** & & o.005*** \\
\hline WTO-Language $^{1}$ & $\begin{array}{l}0.476 * * \\
{[0.022]}\end{array}$ & $\begin{array}{l}\text { o. } 0.498^{* * * *} \\
{[0.034]}\end{array}$ & $\begin{array}{l}0.513 * * * * \\
{[0.035]}\end{array}$ & & $\begin{array}{l}\mathbf{0 . 5 0 2 * * *} \\
\text { o. } 0.035]\end{array}$ & & $\begin{array}{l}0.516^{*} \\
{[0.035]}\end{array}$ & & $\begin{array}{l}0.515 * * * * \\
{[0.035]}\end{array}$ \\
\hline WTO-Holdup ${ }^{1}$ & $-0.306 * * *$ & $-0.319 * * *$ & $-0.366^{* * *}$ & & $-0.309^{* * * *}$ & & $-0.296 * * *$ & & $-0.296 * * * *$ \\
\hline Eurasia & $-0.305 * * *$ & $-0.188^{* * * *}$ & $-0.231 * * * *$ & $\begin{array}{c}-0.193^{* * * *} \\
{[0.040]}\end{array}$ & $\begin{array}{c}{[0.017]} \\
-0.241 * * * \\
{[0.050]}\end{array}$ & $\begin{array}{l}-0.203^{* * * *} \\
{[0.041]}\end{array}$ & & & \\
\hline Eurasia-Remoteness $^{1}$ & $1.442 * * *$ & $\begin{array}{l}0.158 \\
0.030\end{array}$ & 0.129 & & $\begin{array}{l}0.198 \\
0.035\end{array}$ & & & & \\
\hline Eurasia-Infrastructure $^{1}$ & $\begin{array}{l}-0.000 \\
{[0.003]}\end{array}$ & $\begin{array}{l}0.003 \\
{[0.002]}\end{array}$ & $\begin{array}{l}0.002 \\
{[0.002]}\end{array}$ & & $\begin{array}{l}\text { 0.003 } \\
{[0.003]}\end{array}$ & & & & \\
\hline Eurasia-Language $^{1}$ & $\begin{array}{l}0.452 * * * \\
{[0.028]}\end{array}$ & $\begin{array}{l}0.537 * * * \\
{[0.096]}\end{array}$ & $\begin{array}{l}0.522 * * * \\
{[0.097]}\end{array}$ & & $\begin{array}{l}\mathbf{0 . 6 0 4 * * *} \\
{[0.107]}\end{array}$ & & & & \\
\hline Eurasia-Holdup ${ }^{1}$ & $-0.245^{* * * *}$ & $-0.122^{* * * *}$ & $-0.113 * *$ & & 0.009 & & & & \\
\hline ASEAN & & & & $\begin{array}{l}-\mathbf{- 0 . 3 9 0 ^ { * * }} \\
{[0.160]}\end{array}$ & $\begin{array}{l}0.095 \\
{[0.627]}\end{array}$ & $\begin{array}{l}-0.405 * * \\
{[0.162]}\end{array}$ & $\begin{array}{c}0.06 \\
{[0.638]}\end{array}$ & $\begin{array}{c}-0.378^{* *} \\
{[0.162]}\end{array}$ & $\begin{array}{l}0.057 \\
{[0.638]}\end{array}$ \\
\hline ASEAN-Remoteness $^{1}$ & & & & & $\begin{array}{l}0.186 \\
0.290 \mid\end{array}$ & & $\begin{array}{l}0.059 \\
0.294]\end{array}$ & & $\begin{array}{l}0.062 \\
{[0.294]}\end{array}$ \\
\hline ASEAN-Infrastructure $^{1}$ & & & & & $\begin{array}{l}-0.007 \\
{[0.017]}\end{array}$ & & $\begin{array}{l}-0.004 \\
{[0.016]}\end{array}$ & & $\begin{array}{l}-0.005 \\
{[0.016]}\end{array}$ \\
\hline ASEAN-Language $^{1}$ & & & & & 0.287 & & 0.313 & & 0.312 \\
\hline ASEAN-Holdup ${ }^{1}$ & & & & & $-0.862 * *$ & & -0.687 & & -0.47 \\
\hline SAARC & & & & 0.025 & {$[0.428]$} & & {$[0.435]$} & & {$[0.435]$} \\
\hline & & & & {$[0.286]$} & {$[1.147]$} & & & & \\
\hline SAARC-Remoteness ${ }^{1}$ & & & & & 0.368 & & & & \\
\hline SAARC-Infrastructure $^{1}$ & & & & & 0.028 & & & & \\
\hline SAARC-Language ${ }^{1}$ & & & & & {$[0.032]$} & & & & \\
\hline & & & & & $\begin{array}{l}-2.324^{* * 4} \\
{[1.071]}\end{array}$ & & & & \\
\hline SAARC-Holdup ${ }^{1}$ & & & & & -0.234 & & & & \\
\hline EU & & & & $-0.709^{* * *}$ & $\begin{array}{l}10.7321 \\
-0.272 \\
0.166\end{array}$ & $-0.706 * * *$ & $-0.328 * *$ & $-0.734 * * *$ & $\begin{array}{l}-0.328 * * \\
{[0.167)}\end{array}$ \\
\hline EU-Remoteness ${ }^{1}$ & & & & & $\begin{array}{l}0.052 \\
\text { 0.050 } \\
\text { 10.090 }\end{array}$ & & $=\begin{array}{c}{[0.1675} \\
0.075 \\
{[0.088]}\end{array}$ & & $=\quad-0.073$ \\
\hline EU-Infrastructure ${ }^{1}$ & & & & & -0.011 & & $\begin{array}{l}-0.009 \\
-009\end{array}$ & & -0.009 \\
\hline EU-Language $^{1}$ & & & & & $-0.823^{* * * *}$ & & $-0.815^{* * * *}$ & & $-0.814^{* * * *}$ \\
\hline EH-Heldun 1 & & & & & {$[0.305]$} & & [0.295] & & [0.295] \\
\hline EU-Holdup ${ }^{1}$ & & & & & -0.086 & & 0.124 & & 0.124 \\
\hline cis & & & & $1.709^{* * *}$ & $2.373^{* * * *}$ & & [0.116] & & \\
\hline CIS-Remoteness $^{1}$ & & & & & $\begin{array}{l}{[0.327]} \\
-\mathbf{0 . 0 2 0}\end{array}$ & & & & \\
\hline & & & & & {$[0.180]$} & & & & \\
\hline CIS-Infrastructure $^{1}$ & & & & & 0.007 & & & & \\
\hline CIS-Language $^{1}$ & & & & & 0.180 & & & & \\
\hline & & & & & [0.451] & & & & \\
\hline CIS-Holdup $^{1}$ & & & & & -0.132 & & & & \\
\hline RIC & & & & -0.579 & 0.799 & & & & \\
\hline RIC-Remoteness $^{1}$ & & & & & $\begin{array}{l}{[1.3199} \\
1.829\end{array}$ & & & & \\
\hline DrC I In & & & & & [1.995] & & & & \\
\hline RIC-Infrastructure ${ }^{1}$ & & & & & 0.049 & & & & \\
\hline ECO & & & & $0.415 * *$ & $0.975^{*}$ & $0.700^{* * * *}$ & $\begin{array}{l}1.949 * * * \\
{[0.610]}\end{array}$ & $\begin{array}{l}0.700^{* * * *} \\
0.186]\end{array}$ & $\begin{array}{l}1.950 * * * * \\
{[0.610]}\end{array}$ \\
\hline ECO-Remoteness $^{1}$ & & & & & 0.106 & & -0.583 & & $-0.860^{* * *}$ \\
\hline ECO-Infrastructure ${ }^{1}$ & & & & & 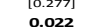 & & $\begin{array}{l}{[0.336]} \\
\mathbf{0 . 0 1 7}\end{array}$ & & $\begin{array}{l}{[0.336]} \\
\mathbf{0 . 0 1 8}\end{array}$ \\
\hline & & & & & {$[0.021]$} & & {$[0.024]$} & & {$[0.024]$} \\
\hline ECO-Language $^{1}$ & & & & & 0.710 & & & & \\
\hline ECO-Holdup ${ }^{1}$ & & & & & $\begin{array}{l}{[1.145]} \\
\mathbf{0 . 3 8 9}\end{array}$ & & 0.052 & & 0.052 \\
\hline tencrup & & & & & {$[0.378]$} & & [0.390] & & {$[0.390]$} \\
\hline CES & & & & & & $\begin{array}{l}-0.046 \\
{[0.140]}\end{array}$ & $\begin{array}{c}0.07 \\
{[0.851]}\end{array}$ & & \\
\hline CES-Remoteness $^{1}$ & & & & & & & $\begin{array}{l}0.193 \\
{[0.265]}\end{array}$ & & \\
\hline CES-Infrastructure ${ }^{1}$ & & & & & & & 0.006 & & \\
\hline 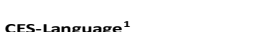 & & & & & & & {$[0.064]$} & & \\
\hline & & & & & & & 0.625 & & \\
\hline CES-Holdup $^{1}$ & & & & & & & 0.029 & & \\
\hline EurAsEC-5 & & & & & & & {$[0.608]$} & & \\
\hline & & & & & & {$[0.110]$} & $\begin{array}{l}0.031 \\
{[0.476]}\end{array}$ & & \\
\hline EurAsEC-5-Remoteness ${ }^{1}$ & & & & & & & 0.271 & & \\
\hline EurAsEC-5-Infrastructure $^{1}$ & & & & & & & $=\quad-0.001$ & & \\
\hline EurAsEC-5-Language $^{1}$ & & & & & & & {$[0.040]$} & & \\
\hline & & & & & & & {$[0.250]$} & & \\
\hline EurAsEC-5-Holdup ${ }^{1}$ & & & & & & & -0.183 & & \\
\hline EurAsEC-3 & & & & & & & {$[0.403]$} & 0.313 & 0.68 \\
\hline EurAsEC-3-Remoteness ${ }^{1}$ & & & & & & & & & 0.176 \\
\hline EurAsEC-3-Infrastructure $^{1}$ & & & & & & & & & 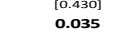 \\
\hline Central Asia & & & & & & $0.767 * *$ & & 0 708*** & [0.058] \\
\hline & & & & & & [0.345] & [1.487] & [0.345] & $\begin{array}{l}0.541 \\
{[1.484]}\end{array}$ \\
\hline Central Asia - Remoteness ${ }^{1}$ & & & & & & & 0.912 & & 0.914 \\
\hline Central Asia - Infrastructure $^{1}$ & & & & & & & {$[0.687]$} & & [0.687] \\
\hline & & & & & & & $\begin{array}{l}0.033 \\
{[0.042]}\end{array}$ & & $\begin{array}{l}0.032 \\
{[0.041]}\end{array}$ \\
\hline Central Asia - Language $^{1}$ & & & & & & & $\begin{array}{l}-0.499 \\
{[1.304]}\end{array}$ & & $\begin{array}{l}-0.542 \\
{[1.293]}\end{array}$ \\
\hline Constant & $\begin{array}{c}-23.718 * * * * \\
{[2.046]}\end{array}$ & $\begin{array}{c}-14.433 * * * \\
{[1.858]}\end{array}$ & $\begin{array}{c}-13.863 * * * * \\
{[1.905]}\end{array}$ & $\begin{array}{c}-13.009 * * * * \\
{[1.892]}\end{array}$ & $\begin{array}{c}-13.835 * * * * \\
{[1.905]}\end{array}$ & $\begin{array}{l}-12.992 * * * \\
{[1.898]}\end{array}$ & $\begin{array}{l}-13.7900^{* * *} \\
{[1.914]}\end{array}$ & $\begin{array}{c}-13.283^{* * * *} \\
{[1.898]}\end{array}$ & $\begin{array}{c}-13.833 * * * \\
{[1.914]}\end{array}$ \\
\hline Observations & 118415 & 118415 & 118415 & 118415 & 118415 & 118415 & 118415 & 118415 & 118415 \\
\hline R-squared & 0.774 & 0.909 & 0.909 & 0.909 & 0.909 & 0.909 & 0.909 & 0.909 & 0.909 \\
\hline Number of nol & & 10232 & 10232 & 10232 & 10232 & 10232 & 10232 & 10232 & 10232 \\
\hline Hausman & & -139.9 & 792.2 & 1701 & 1241 & 888.8 & 496.3 & 751.7 & 495.8 \\
\hline
\end{tabular}


Figure 1: Dynamics of the CIS Trade Openness $\left[\frac{\text { Exports }+ \text { Imports }}{\text { GDP }} \times 100\right]$

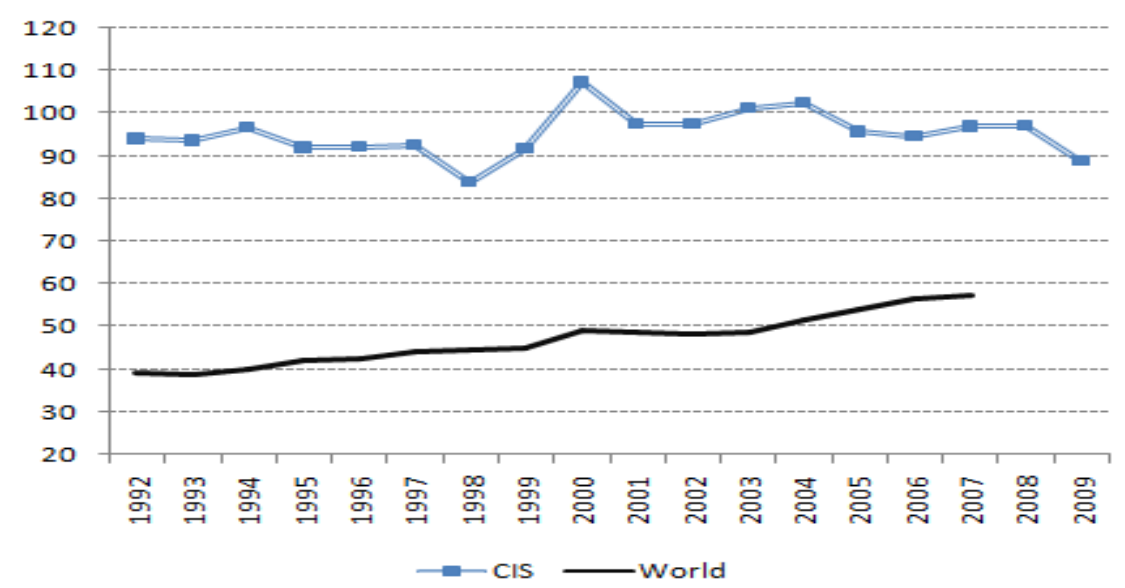

Source: WDI, World Bank

Figure 2: Intra-regional Trade in the CIS: 2008 (in \%)

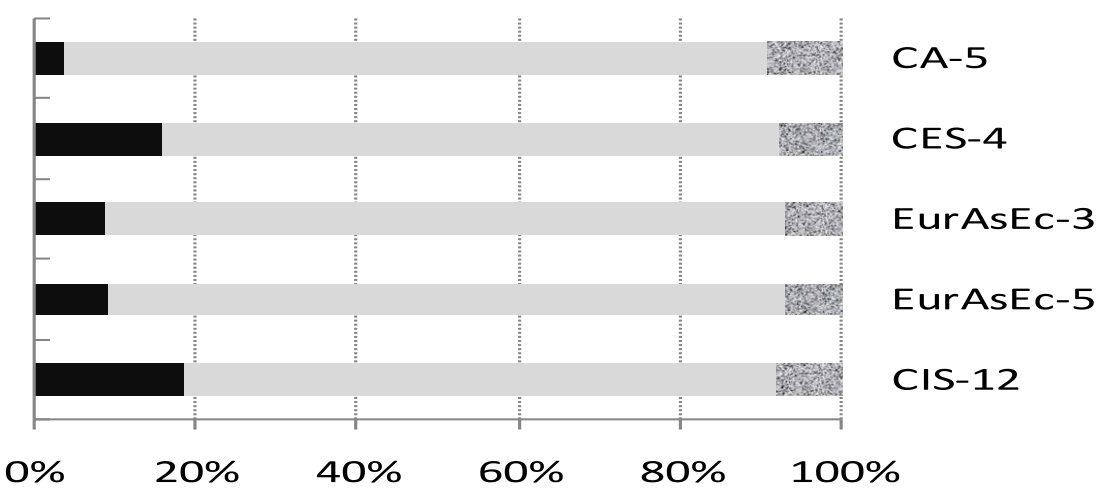

nintra-region rest of Eurasia rest of the world

Source: DOTS, IMF, authors' calculations. 
Figure 3: Structure of trade in the CIS: 2008

Total exports

Intra-regional trade

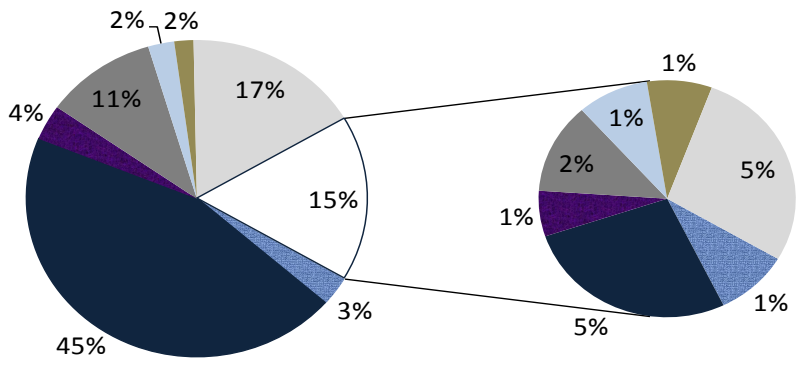

Animal, Vegetable \& Food

- Mineral Products

- Chemicals

Metals: Iron, steel and products

Machinery; Electrical Equipment/Appliances

- Vehicles, Aircraft, Vessels \& Associated Transportation Equipments

Others

Source: TradeMap, WTC

Figure 4: Evolution of RTA Dummies
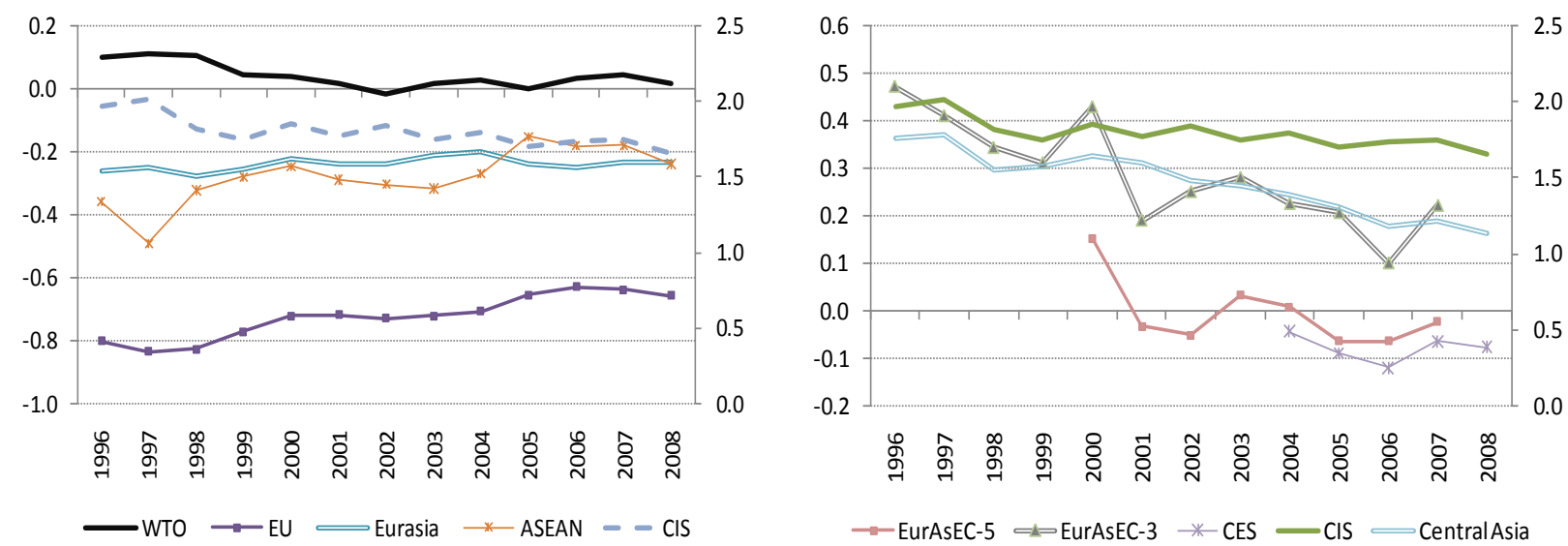
Figure 5: Realization of Trade Potentials: actual trade over potential trade

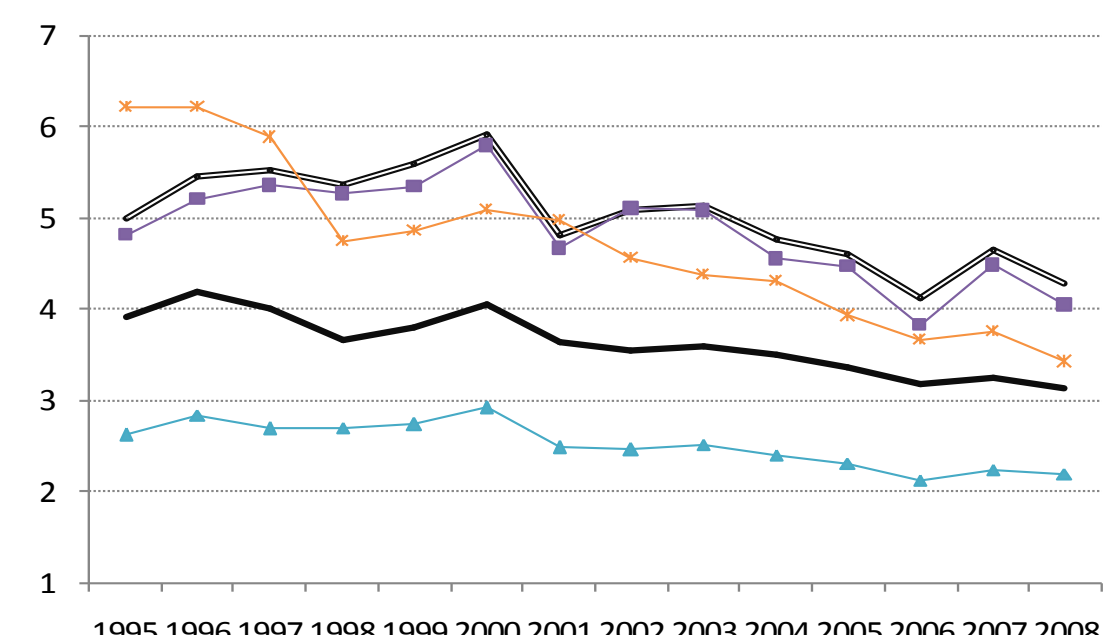

19951996199719981999200020012002200320042005200620072008

$\longrightarrow$ CIS EurAsEC-5 - EurAsEC-3 $\leadsto$ CES $*$ Central Asia 